\title{
LENGTH OF MAINTENANCE OF NATURALLY FORMED AND EXPERIMENTALLY INDUCED CORPORA LUTEA IN HYSTERECTOMIZED EWES
}

\author{
GUY H. KIRACOFE* AND HAROLD G. SPIES \\ Department of Animal Husbandry, Kansas State University, \\ Manhattan, Kansas, U.S.A.
}

(Received 21st August 1965)

\begin{abstract}
Summary. Hysterectomy in ewes 3 to 6 days post-oestrus resulted in prolonged corpora lutea maintenance; luteal regression, however, had occurred by about 150 days post-oestrus. Hysterectomized ewes reovulated after luteal regression and maintained the resulting corpora lutea for a similar period of time. Corpora lutea induced with exogenous gonadotrophins after hysterectomy regressed asynchronously with naturally formed corpora lutea present at the time of the induced ovulation, and the significance of this is discussed.

Hysterectomy during anoestrus resulted in ovulation without oestrus and maintenance of subsequent corpora lutea.
\end{abstract}

\section{INTRODUCTION}

Inskeep, Oloufa, Pope \& Casida (1963) have suggested that corpora lutea of ewes regress at the end of the normal oestrous cycle due to a factor extrinsic to the gland itself, since experimentally induced corpora lutea regress synchronously with naturally formed corpora lutea regardless of their age. The nongravid uterus appears to be involved in provoking a luteolytic stimulus near the end of the oestrous cycle (Short, 1964), while a luteotrophin may play a more dominant role in corpora lutea maintenance beyond the oestrous cycle (Denamur \& Mauléon, 1963). Hysterectomy in the ewe, as in several other species (see Anderson, Bowerman \& Melampy, 1963), results in prolonged maintenance of the corpus luteum beyond the normal oestrous cycle length (Wiltbank \& Casida, 1956: Denamur \& Mauléon, 1963; Moor \& Rowson, 1964).

The present study was designed to: (1) determine the life span of corpora lutea in hysterectomized ewes, (2) compare luteal regression of experimentally induced and naturally formed corpora lutea in hysterectomized ewes, and (3) observe corpora lutea formed in ewes hysterectomized during anoestrus.

\section{MATERIAL AND METHODS}

Black- or white-faced crossbred Rambouillet ewes were checked daily for occurrence of oestrus before and during the experimental period using raddled

* Present address: Department of Anatomy, University of Kentucky Medical Center, Lexington, Kentucky. 
vasectomized rams. Ewes having cycle lengths of 15 to 19 days were randomly assigned to an experimental group in trials 1 and 2. The day of oestrus was designated as Day 1. Hysterectomy consisted of removal of the uterus from mid-cervix to the tubo-uterine junction, with or without oviducts, by a mid-ventral approach under pentobarbital sodium anaesthesia. Ligations were placed around the cervix, including the posterior uterine arteries and veins, and around the middle uterine arteries and veins. Smaller vessels were crushed with haemostats and cautery was used to prevent bleeding. Care was taken not to interrupt ovarian blood supply. Corpora lutea were marked for subsequent identification at hysterectomy by the injection of a small amount of Indian ink into the gland. When corpora lutea of two ages existed, the younger set was marked with a silk thread loosely looped through the gland.

\section{RESULTS}

SERIES 1: DURATION OF CORPORA LUTEA AFTER HYSTERECTOMY

Nine ewes were hysterectomized 3 to 5 days post-oestrus. Two of the nine ewes returned to oestrus 161 and 167 days following pre-hysterectomy oestrus. Original 'ink marked' corpora lutea had regressed and new corpora lutea were present at laparotomy. The remaining ewes failed to return to oestrus. Two ewes, killed 163 and 169 days from pre-hysterectomy oestrus, had original corpora lutea weighing only 50 and $10 \mathrm{mg}$. One of the two ewes had a new corpus luteum. Corpora lutea appeared small in the remaining five ewes at 160 days; new ovulations, however, could not then be detected. The original corpora lutea were completely regressed and new corpora lutea were present in these five ewes when killed on Days 200 to 208.

\section{SERIES 2: DURATION OF GONADOTROPHIN-INDUGED GORPORA LUTEA AFTER HYSTERECTOMY}

Twelve ewes were hysterectomized on Day 4 or 7 of the oestrous cycle. All ewes received subcutaneous injections of 1000 i.u. of pregnant mare's serum (PMs) between Day 120 and 123 post-oestrus followed $48 \mathrm{hr}$ later by an injection of 1000 i.u. of human chorionic gonadotrophin (HCG). Naturally formed corpora lutea were present in all twelve ewes at laparotomy on Days 125 to 128. In addition, nine of twelve ewes had new corpora lutea in response to PMSHCG injections. Three naturally formed corpora lutea from two ewes enucleated at this laparotomy averaged $397 \mathrm{mg}$. Induced corpora lutea were left intact.

All corpora lutea induced with PMS-HGG appeared vascular and large on Days 153 to 162 following pre-hysterectomy oestrus, while all naturally formed corpora lutea appeared avascular and small. Five naturally formed corpora lutea from five ewes averaged $36 \mathrm{mg}$ in comparison with fifteen induced corpora lutea from five ewes averaging $320 \mathrm{mg}$. Ewes laparotomized 153 to 162 days post-oestrus were killed 101 to 173 days after the ovulating injection. Corpora lutea weights for these ewes are shown in Table 1.

Three ewes failing to ovulate after PMS-HCG injections received no further treatment and served as controls. Two of these ewes returned to oestrus on Days 153 and 157. Subsequent laparotomy revealed regression of the original 
corpora lutea and new ovulations. The remaining ewe was killed on Day 160 and the original corpus luteum weighed $80 \mathrm{mg}$. No evidence of a new ovulation was present.

Two ewes with induced and naturally formed corpora lutea were injected intramuscularly with $1 \mathrm{mg}$ oestradiol-17 $\beta$ daily from Day 140 to slaughter on Day 153 or 162 . Oestradiol was not effective in maintaining the naturally formed corpora lutea (average $41.5 \mathrm{mg}$ ).

Four pregnant ewes, hysterectomized on the 23rd or 33rd day after mating, received intramuscular injections of 2000 i.u. of HCG and $1.5 \mathrm{mg}$ of luteinizing hormone (NIH-LH-B-1, bovine standard) on Day 80 or 97 after mating. All

TABLE 1

ASYNGHRONOUS REGRESSION OF NATURALLY FORMED AND EXPERIMENTALLY INDUCED CORPORA LUTEA 77 TO 125 DAYS POST-OESTRUS IN HYSTERECTOMIZED EWES

\begin{tabular}{|c|c|c|c|}
\hline \multicolumn{2}{|c|}{ Age of corpora lutea (days) } & \multicolumn{2}{|c|}{ Average weight of corpora lutea ( $\mathrm{mg}$ ) } \\
\hline Induced & Original & Induced & Original \\
\hline $\begin{array}{c}31 \\
31 \\
38 \\
38 \\
81 \\
84 \\
101 \\
131 \\
150 \\
153 \\
153 \\
163 \ddagger \\
164 \ddagger \\
172 \ddagger \\
173 \ddagger \\
173\end{array}$ & $\begin{array}{l}153 \$ \\
155 \\
124 \dagger \\
162 \$ \\
161 \\
161 \\
226 \\
- \\
122 \dagger \\
277 \\
277 \\
243 \\
261 \\
269 \\
270 \\
297\end{array}$ & $\begin{array}{l}613(1)^{*} \\
440(1) \\
456(2) \\
383(3) \\
193(5) \\
278(3) \\
391(4) \\
243(3) \\
206(3) \\
236(3) \\
139(1) \\
20(3) \\
125(4) \\
70(6) \\
40(5) \\
20(1)\end{array}$ & $\begin{array}{r}73(1) \\
20(1) \\
370(2) \\
10(1) \\
17(1) \\
20(1) \\
20(1) \\
50(1) \\
450(1) \\
10(2) \\
10(1) \\
20(1) \\
30(1) \\
19(1) \\
30(1) \\
10(1)\end{array}$ \\
\hline
\end{tabular}

* Number of corpora lutea in parentheses.

† Original corpora lutea enucleated at laparotomy following induction of new corpora lutea; induced corpora lutea collected at sacrifice 38 or 150 days after induced ovulation.

Ewes hysterectomized when 23 or 33 days pregnant.

$\$$ Daily injections of oestradiol-17 $\beta$ given from Day 140 .

four ewes possessed naturally formed and induced corpora lutea at laparotomy 3 days later. A second laparotomy 161 to 181 days after mating revealed regression of naturally formed corpora lutea and maintenance of induced corpora lutea. Induced corpora lutea averaged $60 \mathrm{mg}$ at autopsy 163 to 173 days from the $\mathbf{L H}-\mathrm{HCG}$ injection.

\section{SERIES 3: HYSTERECTOMY IN ANOESTRUS}

Seven black-faced, crossbred Rambouillet ewes in anoestrus were hysterectomized between 1st June and 20th July. None exhibited oestrus for at least 1 month before hysterectomy nor before autopsy between 12th September and 16 th October. One ewe, killed 10 days after hysterectomy, had not ovulated. The other six ewes possessed corpora lutea 53 to 123 days after hysterectomy. 
The corpus luteum of one ewe was marked at laparotomy on 8th October and appeared large and vascular 23 days later. Nine corpora lutea from the six ewes averaged $382 \mathrm{mg}$ at autopsy. No corpora albicantia could be detected in hysterectomized ewes with corpora lutea. Intact ewes of similar breeding and management had had 2 to 5 cycles by this date; therefore, it was concluded that only one ovulation had occurred after the onset of the breeding season in the hysterectomized ewes.

\section{DISCUSSION}

The uterus appears to have a major influence on the time of luteal regression in the cycling ewe (Kiracofe \& Spies, 1964; Moor \& Rowson, 1964). Short (1964) suggested that a uterine luteolysin in the non-gravid cycle of the ewe provokes corpora lutea regression. The luteolytic stimulus appears to provoke luteal regression of corpora lutea of varying ages simultaneously at the expected time for the naturally formed corpora lutea (Inskeep et al., 1963).

Corpora lutea maintenance to about 150 days after hysterectomy suggests that the stimulus for luteal regression in hysterectomized differs from that in cycling ewes. If regression after hysterectomy were in response to a luteolysin, then the luteolysin could not have been of uterine origin and must have affected only corpora lutea of a given age. The corpus luteum of the long-term hysterectomized ewe, however, may regress due to lack of a luteotrophin or it may become insensitive to circulating luteotrophin levels. Denamur \& Mauléon (1963) have presented evidence that a luteotrophin does function in the hysterectomized ewe, since luteal regression occurred following hypophysectomy on Day 20.

Independent regression of induced and naturally formed corpora lutea in the present study suggests that luteal regression aiter hysterectomy could not be fully explained as due to the lack of a luteotrophin. Induced corpora lutea were maintained past the time of regression of naturally formed corpora lutea whether the latter were left intact or removed. Thus, luteal tissue may have become insensitive to a given level of luteotrophin, resulting in regression by approximately 150 days.

Hysterectomy during anoestrus in the ewe did not interfere with subsequent ovulation and corpus luteum formation. Ovulation occurred in the absence of oestrus, and corpora lutea were maintained to the time of killing. Absence of progesterone has been suggested by Robinson (1954), to account for lack of oestrus at the time of ovulation.

\section{ACKNOWLEDGMENTS}

Appreciation is expressed to Dr Carl Menzies for provision of facilities and management of the experimental sheep. The authors also are indebted to the Endocrinology Study Section, National Institutes of Health, for the NIH-LH-B-1 and to The Upjohn Company for the PMS and HGG.

This investigation was supported in part by funds provided in grant HD00392 from the National Institutes of Health. Contribution No. 336, Department of Animal Husbandry, Kansas Agricultural Experiment Station, Manhattan. 


\section{REFERENCES}

Anderson, L. L., Bowerman, A. M. \& Melampy, R. M. (1963) Neuro-utero-ovarian relationships. Advances in Neuroendocrinology, chap. 11. Ed. A. V. Nalbandov. University of Illinois Press, Urbana, Illinois.

Denamur, R. \& Mauléon, P. (1963) Contrôle endocrinien de la persistance du corps jaune chez les Ovins. C. r. hebd. Séanc. Acad. Sci., Paris, 257, 527.

Inskeep, E. K., Oloufa, M. M., Pope, A. L. \& CAsidA, L. E. (1963) Functional capabilities of experimentally induced corpora lutea in ewes. 7. Anim. Sci. 22, 159.

KIRACOFE, G. H. \& SPIEs, H. G. (1964) Late luteal hysterectomy and uterine extracts in ewes. (Abstract). 7. Anim. Sci. 23, 908.

Moor, R. M. \& Rowson, L. E. A. (1964) Influence of the embryo and uterus on luteal function in the sheep. Nature, Lond. 201, 522.

Robinson, T. J. (1954) The necessity for progesterone with estrogen for the induction of recurrent estrus in the ovariectomized ewe. Endocrinology, 55, 403.

Short, R. V. (1964) Ovarian steroid synthesis and secretion in vivo. Recent Prog. Horm. Res. 20, 303.

Wiltbank, J. N. \& Casida, L. E. (1956) Alteration of ovarian activity by hysterectomy. F. Anim. Sci. $15,134$. 